\title{
PENERAPAN DISCOVERY LEARNING BERBANTUAN MEDIA VISUAL UNTUK MENINGKATKAN HASIL BELAJAR IPS
}

\author{
I Dewa Ayu Ratnadewi ${ }^{1}$, Ni Wayan Arini ${ }^{2}$ \\ 1,2Jurusan Pendidikan Guru Sekolah Dasar, FIP \\ Universitas Pendidikan Ganesha \\ Singaraja, Indonesia \\ email : ratnadewiidewaayu@gmail.com ${ }^{1}, \underline{\text { niwayan.arini@undiksha.ac.id }^{2}}$
}

\begin{abstract}
Abstrak
Penelitian ini bertujuan untuk meningkatkan hasil belajar IPS melalui penerapan discovery learning berbantuan media visual siswa kelas VB SDN 1 Banjar Jawa tahun ajaran 2017/2018. Jenis penelitian ini adalah penelitian tindakan kelas yang dilaksanakan dalam dua siklus. Setiap siklus terdiri dari empat tahap yaitu tahap perencanaan, pelaksanaan, pengamatan, dan refleksi. Subjek penelitian adalah siswa kelas IVB SDN 1 Banjar Jawa sebanyak 38 orang, yang terdiri dari 23 siswa perempuan dan 15 siswa laki - laki. Metode pengumpulan data pada penelitian ini adalah metode tes. Metode analisis data yang digunakan adalah metode analisis kuantitatif, sedangkan teknik analisis data pada penelitian ini adalah teknik analisis deskriptif. Hasil penelitian menunjukan bahwa terjadi peningkatan persentase rerata hasil belajar IPS sebesar $4,08 \%$ dari $82,36 \%$ berada pada kategori tinggi pada siklus I menjadi $86,44 \%$ berada pada kategori tinggi pada siklus II. Selanjutnya peningkatan kuantitas siswa yang mendapat nilai minimal 85 mencapai $31,57 \%$ dari 19 siswa atau 50\% pada siklus I menjadi 31 siswa atau $81,57 \%$ pada siklus II. Berdasarkan hasil analisis data dapat disimpulkan bahwa melalui penerapan model discovery learning berbantuan media visual dapat meningkatkan hasil belajar IPS siswa kelas VB SDN 1 Banjar Jawa tahun ajaran 2017/2018.
\end{abstract}

Kata kunci: discovery learning, hasil belajar IPS, media visual

\section{Abstract}

This research aims to increase social study learning outcomes through discovery learning assisted visual media on VB grade students of SDN 1 Banjar Jawa in academic year 2017/2018. This study used a classroom action research which conducted in two cycles. Each cycle consists of four phases: planning, implementation, observation, and reflection. The subject was VB grade students in SDN 1 Banjar Jawa that included 38 students which consist of 23 female and 15 male. Data collection was done by test method. Social study learning outcomes data were analyzed using quantitative descriptive analysis. The result showed there was an enhancement in the mean percentage of result social study by $4,08 \%$ from $82,36 \%$ as high predicate on the first cycle became $86,44 \%$ as high predicate on the second cycle. Further, improvement quantity of students who received a minimum score of 85 reached $31,575 \%$ from 19 students or $50 \%$ in the first cycle became 31 students or $81,57 \%$ in second cycle. Based on the results of data analysis can be concluded that through the application of visual media -aided discovery learning is proven to improve learning outcomes VB social study graders of SDN 1 Banjar Jawa in academic year $2017 / 2018$.

Keywords: discovery learning, social study learning outcome, visual media 


\section{Pendahuluan}

Siswa merupakan komponen masukan dalam sistem pendidikan, yang selanjutnya diproses dalam proses pendidikan, sehingga menjadi manusia yang berkualitas sesuai dengan tujuan pendidikan nasional. Menurut pasal 1 ayat 4 UU RI No. 20 Tahun 2003 tentang system pendidikan nasional:" Peserta didik adalah anggota masyarakat yang berusaha mengembangkan dirinya melalui proses pendidikan pada jalur jenjang dan jenis pendidikan tertentu “.

Banyak hal yang telah diupayakan pemerintah untuk mengoptimalkan tercapainya tujuan pendidikan yang diinginkan, salah satunya adalah penyempurnaan Kurikulum dan Fokus Pembelajaran. Perubahan paradigma dalam proses pembelajaran yang tadinya berpusat pada guru menjadi pembelajaran yang berpusat pada siswa diharapkan dapat mendorong siswa untuk terlibat secara aktif dalam membangun pengetahuan, sikap dan perilaku. Melalui proses pembelajaran dengan keterlibatan aktif siswa ini berarti guru tidak mengambil hak anak untuk belajar dalam arti yang sesungguhnya. Maka dalam hal ini siswa memperoleh kesempatan dan fasilitas untuk membangun sendiri pengetahuannya sehingga mereka akan memperoleh pemahaman yang mendalam, dan pada akhimya dapat meningkatkan mutu kualitas siswa.

Proses pembelajaran akan optimal jika ada keterlibatan dan interaksi yang baik antara siswa dan guru. Peran guru dalam pembelajaran siswa aktif juga sangat penting. Menurut Undang-Undag No.14 Tahun 2005 "Guru adalah pendidik profesional dengan tugas utama mendidik, mengajar, membimbing, mengarahkan, melatih, menilai, dan mengevaluasi peserta didik pada pendidikan anak usia dini jalur pendidikan formal, pendidikan dasar, dan pendidikan menengah." Guru diharapkan mampu menjadi suri teladan yang dapat ditiru dan digugu oleh peserta didik.

Kenyataan yang terjadi di sekolah proses pembelajaran belum menemukan hasil yang optimal yang sesuai dengan tujuan pendidikan nasional meskipun telah memenuhi standar ketuntasan minimal yang berlaku di sekolah. Siswa masih belum mampu terlibat secara aktif dalam kegiatan pembelajaran, sampai saat ini siswa masih berperan sebagai penerima informasi yang pasif dan hanya menunggu penjelasan dari guru. Hal ini menyebabkan pemahaman yang didapat siswa terbatas dari apa yang mereka dengar dan terima dari guru saja. Walaupun sebenarnya mereka masih mampu mengembangkan pemahamannya tentang materi tersebut.

Berdasarkan hasil observasi dan wawancara yang dilaksanakan oleh peneliti pada tanggal 6 pebruari 2018, wali kelas VB menyatakan bahwa hasil belajar IPS siswa kelas VB SDN 1 Banjar Jawa Kecamatan Buleleng Kabupaten Buleleng siswa terlihat cukup aktif dalam kegiatan pembelajaran. Namun jika melihat nilai rata-rata kelas muatan pelajaran IPS semester satu masih tergolong kurang. Hal ini terlihat dari data yang diperoleh pada muatan pelajaran IPS dari 38 siswa kelas VB semester 1 tahun ajaran 2017/2018, 5 orang siswa berada dalam kategori sangat kurang, 10 siswa terkategori rendah, 20 siswa berada pada katagori sedang dan 3 orang dalam kategori tinggi.

Setelah melakukan refleksi bersama dengan guru, dirasakan oleh guru bahwa hal tersebut disebabkan oleh keterbatasan guru dalam meggunakan model-model pembelajaran yang inovatif dan kreatif, serta masih kurangnya alat bantu yang digunakan untuk penyampaian materi pada tema tersebut. Sementara pada kenyataannya siswa akan lebih memahami suatu materi jika disampaikan dengan alat bantu yang sesuai dengan materi tersebut.

Pengetahuan IPS adalah ilmu pengetahuan yang mengkaji berbagai disiplin ilmu sosial dan humaniora serta kegiatan dasar manusia yang dikemas secara ilmiah dalam rangka memberi wawasan dan pemahaman yang mendalam kepada seluruh peserta didik, khususnya di tingkat dasar dan menengah. Adapun kajian dari pengetahuan IPS antara lain, sosial, ekonomi, budaya, sejarah serta politik (Susanto, 2013:137). Hakikat IPS di sekolah dasar memberikan pengetahuan dasar dan keterampilan sebagai media pelatihan bagi siswa sebagai warga negara sedini mungkin. Karena pendidikan IPS tidak hanya memberikan ilmu pengetahuan semata, tetapi harus berorientasi pada pengembangan keterampilan berpikir kritis, sikap, dan kecakapan-kecakapan dasar siswa yang berpijak pada kenyataan kehidupan 
sosial kemasyarakatan sehari-hari dan memenuhi kebutuhan bagi kehidupan sosial siswa di masyarakat.Belajar IPS untuk siswa SD pada dasarnya bertujuan untuk membuat siswa mampu memahami kehidupan sosial yang ada di lingkungannya. Oleh pentingnya makna dari pembelajaran IPS maka diharapkan hasil belajar IPS harus mampu diraih secara optimal oleh siswa.

Untuk mengoptimalkan pencapaian hasil belajar siswa telah banyak cara yang dilaksanakan oleh pihak-pihak yang berperan dalam bidang pendidikan terutama guru salah satunya dengan cara mengikuti dan melaksanakan pelatihan sepert: seminar, diklat, workshop, Uji Kompetensi Guru dan banyak jenis kegiatan penunjang lainnya. Setelah melaksanakan berbagai kegiatan tersebut diharapkan guru mampu menerapkan Pendekatan Saintifik yang sudah dituangkan dalam Kurikulum 2013. Dalam kurikulum 2013 proses pembelajarannya berlangsung secara tematik dan menggunakan pendekatan saintifik. Pembelajaran tematik adalah "pembelajaran terpadu yang menggunakan tema untuk mengaitkan beberapa mata pelajaran sehingga dapat memberikan pengalaman belajar yang bermakna kepada para peserta didik" (Majid, 2014: 80).

Model pembelajaran discovery learning merupakan nama lain dari pembelajaran penemuan. Sesuai dengan namanya, model ini mengarahkan siswa untuk dapat menemukan sesuatu melalui proses pembelajaran yang dilakoninya. Sani (2014: 97) menyatakan "Pembelajaran Discovery Learning merupakan metode pembelajaran pengetahuan yang menuntut guru lebih kreatif menciptakan situasi yang dapat membuat peserta didik belajar aktif menemukan pengetahuan sendiri". Pada discovery learning materi yang akan disampaikan tidak disampaikan dalam bentuk final akan tetapi peserta didik didorong untuk mengidentifikasi apa yang ingin diketahui dilanjutkan dengan mencari informasi sendiri kemudian mengorganisasi atau membentuk (konstruktif) apa yang mereka ketahui dan mereka pahami dalam suatu bentuk akhir.

Penggunaan model discovery learning dimaksudkan untuk merubah kondisi belajar yang pasif menjadi aktif dan kreatif, mengubah pembelajaran yang teacher oriented ke student oriented, mengubah modus Ekspository peserta didik hanya menerima informasi secara keseluruhan dari guru ke modus Discovery peserta didik menemukan informasi sendiri.

Berdasarkan pemaparan tersebut dapat dikatakan bahwa discovery learning adalah usaha maksimal yang dilakukan oleh warga belajar untuk meningkatkan pengalaman dan hasil belajar dengan menyertakan segala potensi yang ada pada dalam diri dan lingkungan peserta didik.

Di dalam proses belajar, Bruner mementingkan partisipasi aktif dari tiap peserta didik, dan mengenal dengan baik adanya perbedaan kemampuan. Untuk menunjang proses belajar perlu lingkungan memfasilitasi rasa ingin tahu peserta didik pada tahap eksplorasi. Lingkunan ini dinamakan Discovery Learning Environment, yaitu lingkungan dimana peserta didik dapat melakukan eksplorasi, penemuan-penemuan baru yang belum dikenal atau pengertian yang mirip dengan yang sudah diketahui. Lingkungan seperti ini bertujuan agar peserta didik dalam proses belajar dapat berjalan dengan baik dan lebih kreatif.

Dalam discovery learning bahan ajar tidak disajikan dalam bentuk akhir, peserta didik dituntut untuk melakukan berbagai kegiatan menghimpun informasi, membandingkan, mengkategorikan, meng-analisis, mengintegrasikan, mere-organisasikan bahan serta membuat kesimpulan-kesimpulan. Menurut Westwood (2008), pembelajaran dengan metode discovery akan efektif jika terjadi hal-hal berikut: (1) Proses belajar dibuat secara terstruktur dengan hatihati; (2)Siswa memiliki pengetahuan dan keterampilan awal untuk belajar; (2) Guru memberikan dukungan yang dibutuhkan siswa untuk melakukan penyelidikan

Bruner mengatakan bahwa proses belajar akan berjalan dengan baik dan kreatif jika guru memberikan kesempatan kepada peserta didik untuk menemukan suatu konsep, teori, aturan, atau pemahaman melalui contoh-contoh yang ia jumpai dalam kehidupannya (modul Diklat Kurikulum 2013: 38). Pada akhirnya yang menjadi tujuan dalam discovery learning menurut Bruner adalah hendaklah guru memberikan kesempatan kepada peserta didiknya untuk menjadi seorang problem solver, seorang scientist, historin. Melalui kegiatan tersebut peserta didik akan menguasainya, menerapkan, serta menemukan hal-hal yang bermanfaat bagi 
dirinya. Langkah-langkah penerapan discovery learning yaitu: (1) Pemberian rangsangan/stimulasi. Pertama-tama pada tahap ini pebelajar dihadapkan pada sesuatu yang menimbulkan kebingungannya dan timbul keinginan untuk menyelidiki sendiri. Guru dapat memulai kegiatan pembelajarn dengan mengajukan pertanyaan, anjuran membuka buku, dan aktivitas belajar lainnya yang mengarah pada persiapan pemecahan masalah. Stimulasi pada tahap ini berfungsi untuk menyediakan kondisi interaksi belajar yang dapat mengembangkan dan membantu peserta didik dalam mengeksplorasi bahan. Dengan demikian seorang Guru harus menguasai teknik-teknik dalam memberi stimulus kepada peserta didik agar tujuan mengaktifkan peserta didik dapat tercapai; (2) Setelah melakukan stimulation guru memberikan kesempatan kepada peserta didik untuk mengidentifikasi sebanyak mungkin masalah yang relevan dengan bahan pelajaran, kemudian salah satunya dipilih dan dirumuskan dalam bentuk hipotesis (jawaban sementara atas pertanyaan masalah); (3) Pada peserta didik melakukan eksperimen atau eksplorasi, guru memberikan kesempatan kepada peserta didik untuk mengumpulkan informasi sebanyak-banyaknya yang relevan untuk membuktikan benar atau tidaknya hipotesis. Data dapat diperoleh melalui membaca literatur, mengamati objek, wawancara dengan narasumber, melakukan uji coba sendiri dan sebagainya; (4) Pengolahan data merupakan kegiatan mengolah data dan informasi yang telah diperoleh para peserta didik baik melalui wawancara, observasi, dan sebagainya, lalu ditafsirkan; (5) Pada tahap ini peserta didik melakukan pemereksaan secara cermat untuk membuktikan benar atau tidaknya hipotesis yang telah ditetapkan, dihubungkan dengan hasil data processing. Berdasarkan pengolahan dan tafsiran, atau informasi yang ada, pernyataan atau hipotesis yang telah dirumuskan terdahulu itu kemudian dicek, apakah terjawab atau tidak, apakah terbukti atau tidak; (6) Tahap generalisasi/ menarik kesimpulan adalah proses sebuah kesimpulan yang dapat dijadikan prinsip umum dan berlaku untuk semua kejadian atau masalah yang sama, dengan memperhatikan hasil verifikasi. Berdasarkan hasil verifikasi maka dirumuskan prinsipprinsip yang mendasari generalisasi.

Model pembelajaran yang inovatif akan lebih optimal jika dibarengi dengan penggunaan media. Media pembelajaran adalah segala sesuatu yang dapat menyampaikan atau menyalurkan pesan dari suatu sumber secara terencana sehingga terjadi lingkungan belajar yang kondusif dimana penerimanya dapat melakukan proses belajar secara efesien dan efektif. (Rayandra, 2012:8). Media pembelajaran dapat dikelompokkan kedalam beberapa kategori salah satunya adalah media visual. Media visual adalah media yang digunakan hanya mengandalkan indera penglihatan dari peserta didik. Dengan media ini, pengalaman belajar yang dialami peserta didik sangat tergantung pada kemampuan penglihatannya semata. Beberapa media visual antara lain: (a) Media cetak seperti buku,modul,jurnal,peta,gambar dan poster; (b) Model dan prototipe seperti globe bumi; (c) Media realitas alam sekitar dan sebagainya. Secara garis besar, unsur-unsur yang terdapat pada media visual terdiri dari garis, bentuk, warna dan tekstur. Garis merupakan kumpulan dari titik - titik. Bentuk adalah sebuah konsepsi simbol yang dibangun atas garis-garis atau gabungan garis.

Media pembelajaran dapat memberikan manfaat, antara lain: (1) bahan yang disajikan menjadi lebih jelas maknanya bagi siswa dan tidak bersifat verbalistik, (2) metode pembelajaran lebih bervariasi, (3) siswa menjadi lebih aktif melakukan beragam aktivitas, (4) pembelajaran lebih menarik, dan (5) mengatasi keterbatasan ruang. Asyhar (2012: 42) menyatakan, Manfaat media pembelajaran yaitu memperluas cakrawala sajian materi pembelajaran yang diberikan di kelas seperti buku, foto-foto dan narasumber sehingga peserta didik akan memiliki banyak pilihan sesuai kebutuhan dan karakteristik masing-masing.

Beberapa keuntungan jika diterapkan discovery learning yaitu: (1) Membantu siswa untuk memperbaiki dan meningkatkan keterampilan-keterampilan dan proses-proses pengetahuan. Usaha penemuan merupakan kunci dalam proses ini, seseorang tergantung bagaimana cara belajarnya; (2) Pengetahuan yang diperoleh melalui metode ini sangat pribadi dan ampuh karena menguatkan pengertian, ingatan dan transfer; (3) Menimbulkan rasa senang pada siswa, karena tumbuhnya rasa menyelidiki dan berhasil; (4) berpusat pada siswa dan guru berperan sama-sama aktif mengeluarkan gagasan-gagasan. Bahkan guru pun dapat bertindak sebagai siswa, dan sebagai peneliti di dalam situasi diskusi. 
Hal ini didukung oleh penelitian dari Hadiono (2016) disimpulkan bahwa dalam pembelajaran terjadi peningkatan hasil belajar dan motivasi belajar pada siswa kelas VIII D SMPN 2 Kamal dengan menggunakan penerapan discovery learning.

Tota Martiada (2017) By comparing thitung with ttable turns tcounteds ttable, this means the critical thinking ability of students applying discovery learning model is better than students' critical thinking ability with conventional learning. the second hypothesis test obtained tcount = 2.21 with $\alpha=0.05$ obtained ttable $=2.00$. By comparing thit with ttable turns tcounted $>$ ttable, this means the cognitive ability of students applying discovery learning model is better than cognitive ability of students with conventional learning. Dengan membandingkannya dengan ttabel ternyata t hitung > ttabel, ini berarti kemampuan kognitif siswa yang menerapkan model discovery learning lebih baik daripada kemampuan kognitif siswa dengan pembelajaran konvensional.

Sementara itu, penelitian yang dilakukan Widiadnyana (2014) menyatakan bahwa terdapat Pengaruh Model Discovery Learning Terhadap Pemahaman Konsep IPA dan Sikap IImiah Siswa. Juga didukung penelitian Wirahayu (2014) menyatakan bahwa implementasi pembelajaran tematik berbantuan media audio-visual dapat meningkatkan kemampuan membaca, menulis dan berhitung peserta didik kelas I SD Negeri 7 Sesetan semester 2 tahun pelajaran 2012/2013.

Berdasarkan uraian tersebut, maka menarik untuk dilaksanakan Penelitian Tindakan Kelas dengan judul "Penerapan Model Discovery Learning Berbantuan Media Visual Untuk Meningkatkan Hasil Belajar IPS Siswa Kelas VB SD N 1 Banjar Jawa."

Berdasarkan latar belakang masalah yang telah dipaparkan, maka dapat penulis rumuskan masalah sebagai berikut: Apakah penerapan model discovery learning berbantuan media visual dapat meningkatkan hasil belajar IPS siswa kelas VB semester II tahun pelajaran 2017/2018 di SDN 1 Banjar Jawa?

Permasalahan tentang meningkatkan hasil belajar IPS pada siswa kelas VB dapat diatasi melalui penerapan model discovery learning berbantuan media visual yang dikemas dalam suatu kegiatan penelitian tindakan kelas. Dipilihnya model discovery learning berbantuan media visual karena model ini akan membuat siswa belajar lebih aktif, kreatif, menyenangkan, dan cepat mengerti tentang konsep yang baru diajarkan.

Oleh karena itu, diperlukan kemampuan guru secara profesional dalam merancang pembelajaran yang tepat dan sesuai dengan materi yang diajarkan, sehingga siswa lebih memahami dan meningkatkan kemampuannya dalam pembelajaran IPS.

Dari latar belakang dan rumusan masalah yang telah diuraikan, maka tujuan penelitian ini yaitu: Untuk mengetahui peningkatan hasil belajar IPS melalui penerapan model discovery learning berbantuan media visual pada siswa kelas VB SDN 1 Banjar Jawa tahun ajaran 2017/2018.

\section{Metode}

Penelitian yang dilakukan adalah Penelitian Tindakan Kelas (PTK) atau Classroom Action Research. Penelitian Tindakan Kelas adalah proses pengkajian masalah pembelajaran di dalam kelas melalui refleksi diri dan upaya untuk memecahkannya dengan cara melakukan berbagai tindakan yang terencana dalam situasi nyata serta menganalisis setiap pengaruh dari tindakan tersebut (Sanjaya, 2013: 149). Oleh karena itu, rancangan dalam penelitian ini adalah dengan prosedur penelitian tindakan kelas yang dilakukan dalam proses berdaur/bersiklus. Penelitian ini dilakukan dalam 2 siklus Adapun model yang dipilih dalam penelitian ini adalah model PTK menurut Kurt Lewin. Kurt Lewin (dalam Sanjaya, 2013: 154) menjelaskan bahwa "ada empat hal yang harus dilakukan dalam proses penelitian tindakan yakni perencanaan, pelaksanaan, pengamatan dan refleksi". Pada tiap siklus proses pembelajaran dilaksanakan sebanyak 3 kali pertemuan, yang terdiri dari 2 kali pertemuan untuk pemberian tindakan, dan 1 kali pertemuan untuk tes akhir siklus.

Penelitian dilaksanakan di SDN 1 Banjar Jawa pada muatan materi IPS. Penelitian ini dilaksanakan pada semester 2 tahun ajaran 2017/2018 dari bulan Maret sampai dengan bulan April 2018. Subjek penelitian terdiri dari 38 siswa kelas VB dengan siswa laki-laki berjumlah 15 
siswa dan siswa perempuan berjumlah 23 siswa. Objek penelitian adalah hasil belajar IPS siswa kelas VB SDN 1 Banjar Jawa tahun ajaran 2017/2018 dan model discovery learning berbantuan media visual. Metode pengumpulan data yang digunakan dalam penelitian ini adalah metode tes. Metode tes dalam kaitannya dengan penelitian ialah "cara memperoleh data yang berbentuk suatu tugas yang dilakukan atau dikerjakan oleh seorang atau sekelompok orang yang dites, dan dari hasil tes tersebut dapat menghasilkan suatu data berupa skor" (Agung, 2012:66).

Instrumen pengumpulan data metode tes adalah soal. Dalam penelitian ini menggunakan soal objektif jenis pilihan ganda sebanyak 20 butir soal. Skoring atau pemberian skor terhadap jawaban siswa dalam tes objektif bentuk soal pilihan ganda biasa, menggunakan cara dikotomi yaitu skor 1 (satu) untuk jawaban siswa yang benar dan skor 0 (nol) untuk jawaban siswa yang salah.

Selanjutnya data yang telah terkumpul dianalisis. Metode analisis data yang digunakan adalah metode analisis deskriptif kuantitatif. Dalam buku pengantar metodologi penelitian pendidikan, metode analisis deskriptif kuantitatif yaitu "suatu cara pengolahan data yang dilakukan dengan jalan menyusun secara sistematis dalam bentuk angka-angka dan atau presentase, mengenai objek yang diteliti, sehingga diperoleh kesimpulan secara umum" (Agung, 2012:67).

Teknik analisis data yang digunakan dalam penelitian ini adalah teknik analisis statistik deskriptif. Menurut Agung (2014:142) analisis statistik deskriptif adalah cara pengolahan data yang dilakukan dengan jalan menerapkan rumus-rumus statistik deskriptif seperti distribusi frekuensi, grafik, angka rata-rata (Mean), median (Me), dan Modus (Mo) untuk menggambarkan keadaan objek/variabel sehingga diperoleh kesimpulan umum. Selanjutnya hasil analisis persentase hasil belajar pengetahuan siswa yang diperoleh dikonversikan ke dalam Penilaian Acuan Patokan (PAP).

Prosedur penelitian tindakan kelas ini

dilaksanakan sampai tercapainya persentase hasil belajar IPS siswa berada pada kategori tinggi dan hasil belajar pengetahuan IPS 75\% dari 38 siswa mendapat skor minimal 85.

\section{Hasil Dan Pembahasan}

Pelaksanaan pembelajaran selama penelitian dengan menggunakan model discovery learning berbantuan media visual secara umum telah berlangsung sesuai dengan rencana pembelajaran yang telah disusun.

Hasil penelitian siklus I menunjukkan persentase rata-rata hasil belajar IPS mencapai $82,36 \%$ berada pada kategori tinggi. Selanjutnya kuantitas siswa yang memperoleh nilai minimal 85 pada siklus I sebanyak 19 atau 50\%. Dari hasil penelitian tersebut dapat disimpulkan pada siklus I indikator keberhasilan dalam penelitian ini belum tercapai, maka penelitian dilanjutkan ke siklus II. Pelaksanaan tindakan pada siklus II dilakukan didasarkan pada hasil refleksi tindakan pada siklus I. Dari hasil pengamatan dan temuan selama pemberian tindakan pada siklus I terdapat beberapa masalah yang menyebabkan hasil belajar pengetahuan IPS belum mencapai target yang diharapkan. Masalah-masalah tersebut dapat dikemukakan sebagai berikut. (1) Siswa belum terbiasa belajar dengan gaya belajar sesuai dengan model pembelajaran yang diterapkan, sehingga proses pembelajaran belum terlaksana secara efektif. Hal ini disebabkan karena model yang diterapkan merupakan hal baru bagi siswa dan berbeda dengan proses pembelajaran sebelumnya, (2) Masih banyak siswa yang kurang berpartisipasi aktif dalam proses pembelajaran, (3) Dalam diskusi kelompok saat memecahkan masalah/ melakukan percobaan dalam LKPD hanya beberapa siswa yang mengerjakan tugas, sedangkan siswa yang lainnya hanya diam saja dan menunggu hasil.

Saat presentasi terlihat siswa belum percaya diri dalam menyampaikan pendapat atau gagasan.

Mengacu pada kekurangan yang dihadapi pada siklus I, dilakukan diskusi dengan guru untuk merancang perbaikan tindakan untuk selanjutnya diterapkan pada siklus II. Berdasarkan hasil diskusi bersama guru kelas, maka pada siklus II akan dilakukan langkah-langkah 
perbaikan. Adapun langkah-langkah rencana siklus II adalah sebagai berikut: (1) Sebelum melaksanakan tindakan pada siklus II siswa diberikan penjelasan tentang kegiatan atau langkah-langkah pembelajaran yang akan diterapkan agar siswa mengetahui dan memiliki kesiapan dalam mengikuti pembelajaran dengan penerapan model discovery learning berbantuan media visual; (2) Memberikan motivasi dan penguatan kepada siswa agar siswa lebih aktif dalam proses pembelajaran; (3) Dalam diskusi kelompok, guru harus mengawasi serta membimbing siswa sehingga semua siswa ikut terlibat dalam kegiatan diskusi; (4) Guru memberikan motivasi dan penguatan agar siswa berani mengungkapkan pendapat atau jawabannya sehingga siswa menjadi percaya diri dan tidak takut meski jawabannya kurang tepat. Guru memberikan reinforcement pada siswa yang dengan percaya diri menyampaikan pendapat maupun menyampaikan hasil diskusinya.

Setelah dilaksanakan tindakan pada siklus II persentase rata-rata hasil belajar IPS siswa mencapai $86,44 \%$ berada pada kategori sangat tinggi. Selain itu, kuantitas siswa yang memperoleh nilai minimal 85 mengalami peningkatan menjadi 31 atau $81,57 \%$. Dengan demikian persentase rata-rata hasil belajar IPS siswa pada siklus I ke siklus II mengalami peningkatan sebesar $4,08 \%$. Sementara untuk kuantitas siswa yang memperoleh nilai minimal 85 pada siklus I ke siklus II juga mengalami peningkatan sebesar 31,57\%. Adapun peningkatan tersebut dapat dilihat pada tabel berikut.

Tabel 1. Rekapitulasi Hasil Penelitian

\begin{tabular}{ccccc}
\hline & Objek Penelitian & Siklus I & Siklus II & Besar Peningkatan \\
\hline Kuantitas siswa yang & 19 & 31 & 12 \\
Hasil & memperoleh nilai minimal 85 & atau & atau & Atau \\
Belajar & Pou & $51,57 \%$ & $31,57 \%$ \\
IPS & Persentase rata-rata hasil & $82,36 \%$ & $86,44 \%$ & $4.08 \%$ \\
\hline
\end{tabular}

Hasil penelitian menunjukkan hasil belajar pengetahuan IPS pada siklus I belum mencapai kriteria keberhasilan yaitu belum tercapainya $85 \%$ siswa mendapat nilai 85 serta persentase rata-rata hasil belajar pengetahuan IPS siswa belum mencapai minimal $90 \%$ dengan kategori sangat tinggi. Hal ini disebabkan karena siswa belum terbiasa belajar dengan model discovery learning berbantuan media visual, selain itu beberapa orang siswa belum menunjukkan sikap disiplin dan percaya diri saat pembelajaran. Siswa yang kurang disiplin cenderung bermain dengan temannya saat kegiatan diskusi kelompok. Maka dari itu segala upaya dirancang untuk menanggulangi kelemahan pada siklus I dan selanjutnya akan dilaksanakan pada siklus II. Pada siklus II, segala yang dirancang dan diupayakan berjalan dengan lancar sehingga pada siklus II terjadi peningkatan hasil belajar pengetahuan IPS.

Berdasarkan analisis siklus I, kuantitas siswa yang mendapat nilai minimal 85 yaitu sebanyak 19 orang atau 50,00\%, sehingga masih ada 19 siswa yang mendapatkan nilai dibawah 85. Sedangkan pada siklus II kuantitas siswa yang mendapat nilai minimal 85 sebanyak 31 orang atau mencapai $81,574 \%$ hanya terdapat 7 siswa yang belum mendapat nilai 85. Kemudian, hasil analisis siklus I tentang persentase hasil belajar pengetahuan IPS mencapai $82,36 \%$ berada pada kategori tinggi Sedangkan pada siklus II mencapai $76,44 \%$ berada pada kategori hasil belajar pengetahuan IPS tinggi.

Hasil penelitian menunjukkan kuantitas siswa yang memperoleh nilai minimal 85 mengalami peningkatan sebanyak 12 siswa atau $31,15 \%$, sedangkan persentase rata-rata hasil belajar pengetahuan IPS menunjukkan terjadi peningkatan sebesar 4,08\% dari siklus I ke siklus II. belajar IPS secara individu maupun secara rata-rata klasikal secara keseluruhan. Selain itu, sikap siswa sebagai dampak pengiring (nurturant effect) pun mengalami perubahan menjadi lebih baik. Pada proses pembelajaran siklus I, masih ada siswa yang menunjukkan sikap belum percaya diri. Namun setelah dilakukan refleksi dan perbaikan pada proses pembelajaran berupa pemberian reinforcement (hadiah stiker) kepada siswa yang mampu memenuhi kategori 
yang sudah disampaikan guru pada awal pembelajaran, siswa menjadi termotivasi menunjukkan sikap percaya diri. Dengan perubahan sikap yang terjadi pada siswa secara tidak langsung dapat memengaruhi hasil belajar pengetahuan IPS siswa.

Secara umum penelitian ini dapat dikatakan berhasil, karena semua kriteria yang ditetapkan telah terpenuhi. Jadi, dapat dinyatakan bahwa penerapan model discovery learning berbantuan media visual dapat hasil belajar IPS siswa kelas VB semester II tahun pelajaran 2017/2018 di SDN 1 Banjar Jawa. Tota Martiada (2017) By comparing thitung with ttable turns tcounted> ttable, this means the critical thinking ability of students applying discovery learning model is better than students' critical thinking ability with conventional learning. the second hypothesis test obtained tcount $=2.21$ with $\alpha=0.05$ obtained ttable $=2.00$. By comparing thit with ttable turns tcounted> ttable, this means the cognitive ability of students applying discovery learning model is better than cognitive ability of students with conventional learning. Dengan membandingkannya dengan ttabel ternyata t hitung > ttabel, ini berarti kemampuan kognitif siswa yang menerapkan model discovery learning lebih baik daripada kemampuan kognitif siswa dengan pembelajaran konvensional.

Sementara itu, penelitian yang dilakukan Widiadnyana (2014) menyatakan bahwa terdapat Pengaruh Model Discovery Learning Terhadap Pemahaman Konsep IPA dan Sikap IImiah Siswa. Juga didukung penelitian Wirahayu (2014) menyatakan bahwa implementasi pembelajaran tematik berbantuan media audio-visual dapat meningkatkan kemampuan membaca, menulis dan berhitung peserta didik kelas I SD Negeri 7 Sesetan semester 2 tahun pelajaran 2012/2013.

\section{Simpulan dan Saran}

Berdasarkan hasil penelitian dan pembahasan yang telah diuraikan, dapat disimpulkan bahwa penerapan model discovery learning berbantuan media visual dapat meningkatkan hasil belajar IPS siswa kelas VB semester II tahun pelajaran 2017/2018 di SDN 1 Banjar Jawa.

Hal ini dapatdilihat dari hasil analisis siklus I yaitu hasil belajar IPS mencapai $82,36 \%$ berada pada kategori tinggi, 2 siswa mendapat nilai 55, 1 siswa mendapat nilai 60, satu siswa mendapat nilai 65, 2 siswa mendapat nilai 70, 2 siswa mendapat nilai 75 dan 11 siswa mendapat nilai 80 sehingga baru 19 siswa yang mencapai nilai minimal 85 . Sedangkan pada siklus II mencapai $86,44 \%$ berada pada kategori hasil belajar IPS tinggi, dan 31 siswa atau $81,75 \%$ siswa mendapat nilai minimal 85 .

Hal ini menunjukkan terjadi peningkatan pada hasil belajar IPS siswa yaitu kuantitas siswa yang mendapat nilai minimal 85 meningkat sebanyak $31,75 \%$ dari siklus I ke siklus II dan selanjutnya, persentase hasil belajar IPS menunjukkan terjadi peningkatan sebesar 4,08\% dari siklus I ke siklus II dan terjadi peningkatan hasil belajar IPS secara individu maupun secara rata-rata klasikal secara keseluruhan.

Berdasarkan hasil penelitian tindakan ini, disampaikan beberapa saran sebagai berikut: (1)Bagi Kepala SDN 1 Banjar Jawa agar hasil penelitian ini dapat dijadikan dasar untuk membimbing dan mengarahkan staf pengajarnya dalam mengelola kegiatan pembelajaran sehingga pelaksanaan kegiatan pembelajaran menjadi lebih efektif; (2) Bagi guru, model pembelajaran discovery learning berbantuan media visual dapat dijadikan salah satu alternatif desain pembelajaran yang sesuai untuk membelajarkan muatan pelajaran IPS, (3) Bagi peneliti lain, yang berminat mengadakan penelitian lebih lanjut dan sejenis tentang penerapan model discovery learning berbantuan media visual, hendaknya lebih memperhatikan kendala-kendala yang dihadapi siswa dalam pembelajaran serta mengupayakan solusi pemecahan yang tepat agar penelitian yang dilaksanakan dapat mencapai hasil belajar IPS yang lebih maksimal. Penelitian ini dapat dijadikan acuan ataupun referensi demi ketuntasan penelitian selanjutnya.

\section{Daftar Rujukan}

Agung, A.A.Gede. 2010. Pengantar Evaluasi Pendidikan. Singaraja: Universitas Pendidikan Ganesha. 
2012. Metodologi Penelitian Pendidikan. Singaraja: Universitas Pendidikan Ganesha

------. 2014. Metodologi Penelitian Pendidikan. Singaraja: Aditya Media Publishing

------. 2016. Statistika Dasar untuk Pendidikan. Yogyakarta: CV Budi Utama

Arsyad, Azhar. 2012. Media Pembelajaran. Jakarta : PT Rajagrafindo Persada.

Asyhar, Rayandra. 2012. Kreatif Mengembangkan Media Pembelajaran. Jakarta: Referensi Jakarta.

Majid, Abdul. 2014. Pembelajaran Tematik Terpadu. Bandung: PT. Remaja Rosdakarya Offset.

Menteri Pendidikan dan Kebudayaan Republik Indonesia. 2013. 2014. Peraturan Menteri Pendidikan dan Kebudayaan Republik Indonesia Nomor 57 Tahun 2013 Tentang Kurikulum 2013 SD/MI. Jakarta: Kementerian Pendidikan dan Kebudayaan Republik Indonesia.

2015. Materi Pelatihan Guru Implementasi Kurikulum 2013. Jakarta: Kementerian Pendidikan dan Kebudayaan Republik Indonesia.

Menteri Pendidikan dan Kebudayaan Republik Indonesia. 2016. Peraturan Menteri Pendidikan dan Kebudayaan Republik Indonesia Nomor 23 Tahun 2016 Tentang Implementasi Kurikulum. Jakarta: Kementerian Pendidikan dan Kebudayaan Republik Indonesia.

Purwanto. 2009. Evaluasi Hasil Belajar. Yogyakarta: Pustaka Belajar.

Sani, Ridwan Abdullah. 2014. Pembelajaran Saintifik untuk Implementasi Kurikulum 2013. Jakarta: PT. Bumi Aksara.

Sanjaya, Wina. 2013. Penelitian Pendidikan. Jakarta: Kencana Prenada Media Group.

Susanto, Ahmad. 2013. Teori Belajar dan Pembelajaran di Sekolah Dasar. Jakarta: Kencana Prenada Media Group.

Tota,Mortiada. 2017. The Effect of Discovery Learning Model on Student's Critical Thinking and Cognitive Ability in Junior High School. Volume 7, Issue 6 Ver. I

Hadiono. 2016. Penerapan Model Pembelajaran Discovery Learning Untuk Meningkatkan Motivasi Dan Hasil Belajar Siswa Kelas Viii-D Smpn 2 Kamal Materi Cahaya. Jurnal Pena Sains Vol. 3, No. 2. 